WAHANA

AKUNTANSI
JURNAL ILMIAH WAHANA AKUNTANSI

Vol 13 (1) 2018, 39-57

http://journal.unj.ac.id/unj/index.php/wahana-akuntansi

\title{
TRANSFORMASI TATA KELOLA UNIT KERJA BIDANG ADMINISTRASI UMUM DAN KEUANGAN MELALUI PENGUATAN KELEMBAGAAN MENUJU PENCAPAIAN RENSTRA UNJ
}

\section{Suryadi \\ Indra Pahala \\ Karuniana Dianta \\ Universitas Negeri Jakarta}

\begin{abstract}
Peningkatan kualitas pada bidang Administrasi Umum dan Keuangan Universitas Negeri Jakarta (UNJ) merupakan salah satu cara untuk mewujudkan target dari Rencana Strategis (Renstra) UNJ guna menghadapi tantangan perkembangan dunia pendidikan di masa depan dan tuntutan dari stakeholders. Peningkatan kualitas dilakukan dengan cara mengevaluasi capaian target dari masing-masing rencana kerja pada Bidang Administrasi Umum dan Keuangan, khususnya perihal kualitas Sumber Daya Manusia, serta pengelolaan Sarana dan Prasarana di UNJ. Penelitian dilakukan di lingkungan PR II UNJ yang meliputi unit kerja BAUK dan BAPSI berdasarkan gagasan Nee mengenai new sociology economics institutionalism. Gagasan tersebut membagi mekanisme integrasi hubungan formal dan informal pada setiap level kausal, yakni pada tataran mikro (individu) yang dijelaskan sebagai sistem jaringan elemen dalam unit kerja pada penelitian, tataran messo (kelompok ataupun organisasi) yang dijelaskan sebagai bentuk tata kelola unit kerja pada penelitian, dan tataran makro berupa lingkungan kebijakan (policy environment) yang dijelaskan sebagai proses perumusan implementasi kebijakan unit kerja oleh pihak rektorat dalam penelitian. Penelitian dilaksanakan melalui 7 tahapan sesuai pendekatan metode Soft System Methodology (SSM).

Hasil penelitian ini menunjukkan bahwa pada level makro, dalam melaksanakan tugasnya unit kerja bidang administrasi umum dan keuangan selalu melibatkan setiap elemen yang terdapat pada unit kerja ini sesuai dengan kebutuhan dari proses belajar mengajar dari masing-masing fakultas. Proses perumusan kebijakan yang dilakukan sudah sesuai dengan pendekatan Renstra, yakni harus sistemik, imajinatif, dan tidak terikat oleh kontinuetas kegiatan yang telah lalu. Sedangkan, pada level messo, dalam pelaksanaan proses tata kelola, para staf dalam unit ini masih mendapatkan masalah. Masalah yang terjadi terkait masalah akuntabilitas dan keterampilan Sumber Daya Manusia. Pada level mikro, setiap elemen memiliki tata perilaku, norma, kebiasaan, peraturan formal maupun informal dalam melakukan eksekusi setiap rumusan kebijakan yang telah dibuat oleh unit kerja ini. Namun, masih ditemukan masalah sistem jaringan yang menyulitkan bagi setiap elemen pada unit kerja ini. Hasil penelitian juga menunjukkan bahwa bentuk transformasi yang telah dilakukan oleh pihak Universitas Negeri Jakarta adalah dengan melakukan penguatan kelembagaan dalam hal tata kelola setiap unit kerja yang ada di universitas, termasuk dalam unit kerja bidang administrasi umum dan keuangan.
\end{abstract}

How to Cite:

Suryadi, Indra Pahala, dan Karuniana Dianta. (2018). Transformasi Tata Kelola Unit Kerja Bidang Administrasi Umum dan Keuangan Melalui Penguatan Kelembagaan Menuju

Pencapaian Renstra UNJ. Jurnal Ilmiah Wahana Akuntansi, 13(1), 39-57. https://doi.org/10.21009/ wahana.013.1.4 


\section{PENDAHULUAN}

Universitas Negeri Jakarta (UNJ) merupakan sebuah lembaga pendidikan tinggi di Indonesia yang melaksanakan kegiatan Tri Darma Perguruan Tinggi dalam upaya menghasilkan masyarakat Indonesia yang cerdas dan kompetitif. Upaya Universitas Negeri Jakarta (UNJ) dalam menghasilkan masyarakat Indonesia yang cerdas dan kompetitif tersebut dituangkan dalam Rencana Strategis (Renstra) yang menetapkan arah kebijakan UNJ pada tataran konsolidasi dalam rangka mempersiapkan diri untuk mewujudkan keunggulan UNJ secara kompetitif pada tingkat nasional dan internasional. Implementasi pengembangan Renstra UNJ (periode 20062017) dituangkan dalam tiga tahapan, sebagai berikut:

1. Tahap Reposisi dan Konsolidasi (periode 2006-2009). Tahapan ini dilaksanakan dengan mengintervensi perubahan empat fokus pengembangan yaitu tata kelola, sumberdaya manusia, peningkatan kualitas, dan pencitraan publik.

2. Tahap Pemantapan dan Pemandirian (periode 2010-2013). Tahapan ini dimaksudkan agar proses perubahan berlangsung terus-menerus tidak berhenti hanya pada tahapan reposisi dan konsolidasi. Tahap ini lebih menguatkan pada hasil-hasil konsolidasi untuk mencapai kemandirian.

3. Tahap Penguatan dan Perluasan (periode 2014-2017). Tahapan ini dimaksudkan agar perubahan tersistematis dan terpadu dalam tahap integrasi dan mandiri menjadi modal dalam mempercepat proses peningkatan kualitas layanan bertaraf internasional, dengan memanfaatkan seluas-luasnya jejaring kemitraan yang terprogram dan saling menguntungkan.

UNJ harus mengembangkan sejumlah kebijakan pendidikan yang berorientasi pada peningkatan kualitas dan pemecahan masalah guna mencapai target dari setiap tahapan Renstra. Salah satu bidang yang terus ditingkatkan kualitasnya di UNJ dan layanannya harus diberikan secara prima adalah bidang administrasi umum dan keuangan (BAUK). PR II bertanggung jawab dalam mengelola serta melakukan perbaikan dan pengembangan sistem dalam BAUK dan Bidang Administrasi Perencanaan dan Sistem Informasi (BAPSI) melalui penetapan programprogram unggulan sebagai bentuk program kerja pada masa tertentu serta melakukan evaluasi terhadap segala capaian yang telah diraih melalui pelaksanaan sejumlah kegiatan, seperti peningkatan kualitas Sumber Daya Manusia, Pengelolaan Sarana dan Prasarana, serta pengelolaan dalam bidang keuangan.

Evaluasi tersebut bertujan untuk mengungkapkan efektivitas dan efisiensi langkah yang telah dilakukan PR II dalam mengelola BAUK, sehingga dapat pula ditetapkan langkah perbaikan yang dapat diambil untuk peningkatan kualitas. Melalui penelitian ini dapat diperoleh rekomendasi penting untuk perbaikan berkelanjutan dalam BAUK yang sekaligus menjadi acuan dalam 
pengembangan program kerja PR II serta strategi penting yang terkait dengan pengembangan pengembangan UNJ di masa datang.

Hingga tahun 2013 ini, PR II UNJ telah banyak melaksanakan kegiatan dalam bidang administrasi umum dan keuangan. Beberapa dari kegiatan tersebut dapat mencapai target yang telah ditetapkan dalam Renstra UNJ, tetapi sejumlah kegiatan lainnya belum dapat dilaksanakan karena berbagai alasan. Sebagai contoh adalah penyediaan sarana dan prasarana untuk seluruh unit kerja yang ada di UNJ tidak dapat dilaksanakan secara serentak karea adanya keterbatasan dana yang dimiliki UNJ. Dalam hal ini, UNJ harus menetapkan pengembangan sarana dan prasarana berdasarkan skala prioritas. Penyediaan sarana prasarana yang berhubungan dengan kegiatan belajar mengajar dengan tetap memperhatikan target yang telah ditetapkan dalam Renstra perlu menjadi prioritas utama.

PR II memiliki peran strategis dalam mewujudkan UNJ yang kompetitif dan berdaya saing tinggi, karena PR II bertanggung jawab dalam mengembangkan strategi inovatif untuk perbaikan dan tata kelola organisasi UNJ. PR II juga harus mampu untuk menjaga koordinasi kerja di antara unit kerja dan sivitas akademika UNJ. Untuk itu, penelitian ini dilakukan guna memecahkan berbagai permasalahan yang telah berhasil terpantau di lingkungan PR II dengan menggunakan pendekatan New Sociology Economics Institusionalism yang dicetuskan oleh Nee.

Adapun beberapa masalah yang dapat dirumuskan adalah sebagai berikut:

1. Bagaimana unit kerja yang ada dalam cakupan bidang administrasi umum dan keuangan (PR II) melakukan perumusan kebijakan formal dalam setiap kegiatan, terutama yang terkait dengan kebijakan Rektor dalam bidang administrasi umum dan keuangan. Apakah kebijakan yang dirumuskan tersebut sudah sesuai dengan Renstra UNJ?

2. Bagaimana proses pembelajaran dan dinamika dalam tata kelola kelembagaan (governance structure) pada unit kerja bidang administrasi umum dan keuangan, terutama yang terkait dengan proses perumusan impelementasi kebijakan?

3. Bagaimana setiap elemen yang terkait dengan unit kerja bidang administrasi umum dan keuangan melaksanakan rumusan implementasi kebijakan melalui sistem jaringan sosial yang terdapat dalam lingkungan UNJ?

4. Bagaimana bentuk transformasi profesionalisme unit kerja bidang administrasi umum dan keuangan

dikontruksi sebagai bagian dari pengembangan UNJ menjadi universitas yang memiliki keunggulan komparatif dan berdaya saing tinggi?

Penelitian dilakukan dengan tujuan sebagai berikut:

1. Untuk mengetahui bagaimana PR II UNJ memberlakukan kebijakan formal dalam setiap kegiatan kelembagaannya, terutama yang terkait dengan kebijakan Rektor 
dalam bidang sumberdaya manusia, sarana dan prasarana serta keuangan yang tertuang dalam Renstra UNJ.

2. Untuk mengetahui bagaimana proses pembelajaran dan dinamika dalam tata

kelola kelembagaan (governance structure) pada unit kerja di lingkungan PR II, yaitu BAUK dan BAPSI, dalam menjalankan kebijakan Rektor di bidang sumberdaya manusia, sarana dan prasarana serta keuangan.

3. Untuk mengetahui bagaimana unit kerja di lingkungan PR II menjalankan kebijakan Rektor di bidang sumberdaya manusia, sarana dan prasarana serta keuangan menggunakan mekanisme keterlekatan jaringan sosial dengan melibatkan individu ataupun elemen-elemen lain dalam UNJ.

4. Untuk mengetahui bagaimana bentuk transformasi profesionalisme unit kerja di lingkungan PR II dikontruksi.

Dilakukannya penelitian ini dapat menjadi salah satu bahan masukan bagi PR II untuk pengembangan BAUK di masa depan. Selain itu, penelitian juga dapat menjadi sumber informasi terkait dampak dari kebijakan dalam bidang sumberdaya manusia, sarana dan prasarana, serta keuangan yang sudah dilakukan terhadap pengambilan keputusan dan pengembangan Renstra UNJ di masa datang, sekaligus melihat kesesuaian antara kebijakan tersebut dengan Renstra UNJ.

\section{KAJIAN PUSTAKA, KERANGKA PEMIKIRAN, DAN HIPOTESIS}

\section{Implementasi Kebijakan}

Implementasi menurut Van Meter dan Van Horn mcrupakan tindakan yang diarahkan

Badan-

pekerjaan-pckerjaan

suatu tindakan yang mengarah pada tujuan yang diusulkan oleh seseorang, kelompok atau pemerintah dalam lingkungan tertentu sehubungan dengan adanya hambatan-hambatan tertentu seraya mencari peluang-peluang untuk mencapai tujuan atau mewujudkan sasaran yang diinginkan (Wahab, 2008).

Penelitian yang dilakukan oleh Lester dan Stewart menjelaskan bahwa implementasi kebijakan, dipandang dalam pengertian luas, merupakan alat administrasi hukum dimana berbagai aktor, organisasi, prosedur dan teknik yang bekerja bersama-sama untuk menjalankan kebijakan guna meraih dampak atau tujuan yang diinginkan oleh lembaga.

\section{Kelembagaan}

Kelembagaan didefinisikan sebagai batasanbatasan yang dibuat untuk membentuk pola interaksi yang harmonis antara individu dalam melakukan interaksi politik, sosial, dan 
ekonomi (Doglas dan North, 1990). Oliver

Williamson menganalisis perubahan suatu institusi dalam proses kelembagaan yang terjadi pada level social (masyarakat), level formal institutional (kelembagaan formal), level givernance (tata kelola), dan level perubahan yang bersifat kontinu.

\section{Kelembagaan Ekonomi dan Sosiologi Baru} (New Institutionalism in Economics and Sociology)

Victor Nee (2005) dalam Hand Book of NIE 2005:789-813 memulai pemikirannya mengenai New Institutionalism in Ecomics and Sociology (NIES) diawali dengan pemikiran bagaimana interaksi institusi dengan jaringan sosial (social network) dan norma-norma sosial dalam mengambil tindakan ekonominya yang menambahkan pemikiran Granovetter mengenai ketertambatan (embeddeness) pola norma dan kepercayaan dalam suatu sistem jaringan sosial. NIES merupakan tanggapan pendekatan New Institusional Economic (NIE) yang dikemukan oleh Williamsin yang mengemukakan pendapat bahwa dalam setiap kegiatan ekonomi ada hubungan antara institusi formal dan makro yang melahirkan kepercayaan.Nee mengemukakan adanya mekanisme integrasi hubungan formal dan informal pada setiap level kausal, yakni pada tataran mikro (individu), messo (kelompok ataupun organisasi), dan tataran makro berupa lingkungan kebijakan (policy environment), termasuk ketentuan dalam pengembangan sistem dan tata kelola suatu organisasi. Model interaksi hubungan formal oleh Nee dapat dilihat pada Gambar 1 di bawah ini.

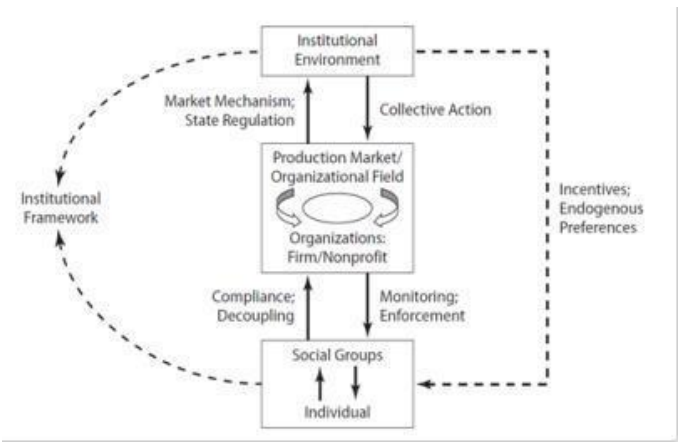

Gambar 1

\section{Model Interaksi Hubungan Formal Nee}

Sumber: Victor Nee (2005) dalam Hand Book of NIE 2005:789-813

Model tersebut menjelaskan keterkaitan antara fungsi lingkungan institusional atau kelembagaan (policy environment) berupa regulasi formal di level makro (regulasi) yang diterapkan oleh pemerintah dalam penataan hak -hak kepemilikan, penataan pasar, dan organisasi profit atau perusahaan yang diintegrasikan dengan aturan formal dan informal di level meso (organisasi) dan juga pada level mikro (grup sosial dan individu) dalam kegiatan ekonominya.

Nee (2005) mengemukakan terjadi mekanisme integrasi hubungan formal dan informal pada setiap level sebab akibat (kausal), yakni pada tataran mikro (individu), meso (kelompok ataupun organisasi), dan tataran makro berupa lingkungan kebijakan (policy environment).

\section{Pembelajaran \\ (Organizational Learning)}

Organisasional

Faktor yang diperlukan dan berpengaruh terhadap terciptanya kondisi organizational learning yang sistematis adalah keberadaan 
struktur organisasi (organizational structure), yaitu tempat dilaksanakannya proses pembelajaran. Dodgson (1993) mendefinisikan learning organization sebagai perusahaan yang secara sengaja mengadopsi struktur-struktur dan strategi-strategi tertentu guna mendorong proses pembelajaran. Selain itu, Organizational learning juga berkaitan erat dengan leadership dalam perusahaan.

Hubungan antara proses organisasi pembelajar dan unsur leadership tercipta karena terdapat kebutuhan organisasi pembelajar untuk beradaptasi terhadap perubahan lingkungan agar dapat bertahan hidup. Keterlibatan unsur leadership dalam organizational learning mewajibkan adanya kajian yang lebih

mendalam mengenai perbedaan aspek transactional dan transformational leadership.

Transactional leadership terjadi ketika manajer mengambil insiatif sendiri dalam menawarkan berbagai bentuk kepuasan yang bernilai bagi karyawannya. Sedangkan, transformational leadership merupakan sebuah proses yang menggabungkan atau mengikutsertakan komitmen dan apresiasi karyawan dalam konteks pembagian nilai dan pembagian visi.

\section{Paradigma Penelitian}

Langkah pertama sebuah penelitian adalah memilih dan menetapkan paradigma penelitian yang dapat dijadikan panduan selama proses

penelitian. Guba (1978) menguraikan paradigma sebagai seperangkat kepercayaan yang melandasi tindakan sehari-hari maupun dalam kaitannya dengan pencarian keilmuan. Melalui penetapan paradigma itulah, seorang peneliti dapat memahami fenomena apa yang akan diteliti, baik berkaitan dengan asumsi bagaimana memandang objek penelitian, dan bagaimana melaksanakan proses penelitian. Paradigma menurut Guba dapat diklasifikasin menjadi empat item, yaitu positivism, post positivism, critical theory, dan constructivism.

\section{Pendekatan Penelitian System Thinking}

Penelitian ini menggunakan pendekatan systems thinking, khususnya metode Soft Systems Methodology (SSM). Berpikir sistemik (System Thinking) adalah disiplin baru untuk memahami kompleksitas dan perubahanperubahan yang terjadi. Syarat awal untuk memulai berpikir sistemik adalah adanya kesadaran untuk mengapresiasi dan memikirkan suatu kejadian sebagai sebuah system.

Metode SSM dalam penelitian menggunakan cara berpikir sistem untuk memahami fenomena yang terjadi dengan menggunakan pemodelan bahasa yang diaplikasikan melalui tujuh langkah analisis berdasarkan konsep human activity system sebagai sarana untuk 'finding out' tentang situasi ke 'taking action' untuk memperbaiki situasi tersebut (Checkland).

Berikut adalah tujuh tahapan dalam aplikasi SSM:

1. Menangkap situasi yang tidak terstruktur melalui persepsi aktor-aktor yang terlibat didalamnya, actor-aktor tersebut meliputi Clients (C), Problem Solver (PractitionerPS), Problem Owner (PO). Terdapat tiga analisis yang dapat dilakukan, yaitu analisa culturals-stream aktor PO, analisa social stream yaitu menggali informasi 
dari aktor PO, dan analisa sistem politik dan aktor PO.

2. Menstrukturkan realitas yang tidak terstruktur di tahapan 1 melalui pembuatan Rich Picture tentang real world yang dibutuhkan untuk membangun Root Definition (RD). Rich Pictures digunakan untuk identifikasi situasi nyatayang dianggap penting sebelum membuat model konseptual.

3. Membuat Root Definition yang relevan dengan sistem. Root definition adalah deskripsi terstruktur dari sebuah sistem aktivitas manusia yang relevan dengan situasi problematis yang menjadi perhatian di dalam penelitian SSM yang berbasistindakanyangdiuji menggunakananalisisCATWOE

(Customer, Aktor, Transformation Process, Weltanschuung, Owner, dan

Environmental coinstraint). Proses Tranformasi pada Tahap ini dikatakan baik jika memenuhi penilaian dengan

kriteria Efficacy, Eficiency, dan Effectiveness (Checkland PB, Poulter J, 2006).

4. Membuat model konseptual dan dilakukan pengujian terhadap mmodel konseptual tersebut. Menurut Checkland (1993), konseptual model adalah model yang menggambarkan kegiatan sistem, dimana elemennya merupakan kata kerja. Kegiatan tersebut dibuat berdasarkan root definition dan struktur kata kerja mengacu pada logika dasar.

5. Melakukan komparasi antara model konseptual dengan dunia nyata. Perbandingan model konseptual yang sudah ditentukan dengan dunia nyata guna menghasilkan perdebatan mengenai persepsi, dan perubahan yang dianggap akan menguntungkan.

6. Perubahan yang telah didapatkan dari perbandingan konseptual, haruslah perubahan yang yang memperhitungkan 'culturally feasible' dan 'systematically desirable'.

7. Terakhir adalah tahap pelaksanaan atau action.

\section{OBJEK DAN METODOLOGI PENELITIAN}

\section{Tempat dan Waktu}

Penelitian ini dilakukan di lingkungan PR II UNJ yang meliputi unit kerja BAUK dan BAPSI. Penelitian dilaksanakan selama 7 bulan, terhitung dari bulan Mei hingga Desember 2013.

\section{Prosedur Penelitian}

Pendekatan yang digunakan pada penelitian ini adalah pendekatan systems thinking, yaitu metode Soft Systems Methodology (SSM). Pada metode ini digunakan cara berpikir sistem untuk memahami fenomena yang terjadi dengan menggunakan pemodelan bahasa (modelling language).

Penelitian dilakukan dengan mengikuti tujuh tahapan yang disyaratkan oleh metode SSM, yaitu tujuh tahapan analisis berdasarkan konsep Human Activity, sebagai berikut:

1. Pengungkapan situasi yang tidak 
terstruktur menurut para actor yang terlibat.

2. Pembuatan Rich Picture yang menggambarkan dunia nyata.

3. Membangun Root Definition (RD).

4. Membuat dan menguji Konseptual Model.

5. Melakukan komparasi antara Konseptual Model dengan dunia nyata.

6. Mendisukusikan kembali model yang sudah dibangun dengan aktor PO yang sudah memberikan masukan tentang perubahan yang diharapkan.

7. Melakukan tindakan.

\section{Teknik Pengumpulan Data}

Data dikumpulkan berdasarkan Studi Pustaka dan dokumentasi berkenaan dengan bidang Keuangan, SDM dan Sarana \& Prasarana, serta data-data statistik. Selain itu, dilakukan pula wawancara mendalam (depth interview) untuk memperoleh data tentang persepsi dan refleksi atas permasalahan kebijakan bidang keuangan, SDM, serta sarana dan prasarana.

\section{Responden Penelitian}

Beberapa responden penilitian diantaranya sebagai berikut:
1. Pembantu Rektor II Universitas Negeri Jakarta.

2. Staf pada Unit Kerja Pembantu Rektor II UNJ.

3. Kepala Bagian Keuangan Universitas Negeri Jakarta.

4. Kepala Bagian Kepegawaian Universitas Negeri Jakarta.

5. Kepala Bagian Sarana dan Prasana
Universitas Negeri Jakarta.
6. Kepala Sub Bagian
Monitoring Universitas Negeri Jakarta.

\section{PEMBAHASAN}

\section{Tahap 1: Menggambarkan Situasi Permasalahan}

\section{Analisis Satu: Analisis Cultural Stream}

a. Level Makro. Pada level makro dijelaskan bagaimana bentuk dan proses perumusan implementasi kebijakan turunan dari UU dan Peraturan Pemerintah berkaitan dengan sistem pendidikan nasional dan pendidikan tinggi yang dibuat oleh pihak rektorat UNJ untuk mempermudah proses pelayanan demi tercapainya tujuan renstra UNJ 2014. Hal ini berkaitan dengan perubahan Badan Hukum UNJ dari awalnya IKIP. Perubahan ini diikuti dengan perubahan struktur tata kelola UNJ, salah satunya adalah permasalahan UKT. Sebagai Universitas dengan status BLU, PR II melalui BAUK dan BAPSI, melakukan perencanaan dan perancangan UKT bersama dengan seluruh elemen unit kerja di UNJ.

b. Level Messo. Pada level Messo dibahas bagaimana proses tata kelola dan tata kerja pada unit kerja BAUK, yaitu pada unit kerja BUP (Biro Umum dan Perencanaan) yang melaksanakan fungsinya sebagai pelaksanaan urusan rumah tangga, sarana dan prasarana, tata usaha, 
hukum dan tatalaksana. Selain itu, tata kelola kinerja BKP (Bidang Penganggaran Akuntansi, dan Keuangan) turut di bahas terkait pengelolaan dana Universitas yang berasal dari masyarakat, berdasarkan status BLU.

c. Level Mikro. Pada level mikro dijelaskan bagaimana sistem jaringan yang ada pada setiap pola tindakan dari setiap elemen-elemen unit kerja BAUK. Diperoleh hasil bahwa sistem jaringan yang digunakan dalam tingkatan elemen-elemen unit kerja BAUK adalah standar perilaku. Setiap tindakan yang dilakukan semuanya terikat dengan nilai-nilai yang telah lahir dan berkembang pada sistem tata kerja dan tata kelola di lingkungan kerja UNJ pada umumnya dan unit kerja BAUK pada khususnya.

\section{Analisis Dua}

a. Analisis Sosial Stream. Analisis ini digambarkan melalui tiga elemen sosial yang meliputi Peran, Norma, dan Nilai. Memberikan hasil bahwa peran yang di mandatkan pada BAUK oleh Rektorat adalah membuat rumusan implementasi dari setiap kebijakan turunan yang dibuat oleh rektortat terutama yang terkait dengan tata kerja badan layanan umum BAUK yang terkait langsung pada sistem kerja dan pelayanan yang dilakukan untuk tercapainya renstra UNJ 2014. Adapun nilai-nilai yang dipertimbangkan dalam Level Makro meliputi nilai yang dianut oleh BAUK dalam mewujudkan Renstra UNJ 2014. Sedangkan, nilai pada level Makro meliputi nilai keadilan, persamaan, kebersamaan (solidaritas), kemandirian dan transparansi. Seain itu, pada level Messo diperoleh nilai kemandirian, optimis, kebersamaan dan solidaritas.

b. Analisis Sistem Politik. Analisis politik memberikan gambaran mengenai

kekuatan yang penuh dalam memutuskan terjadi atau tidaknya sesuatu hal. Analisis politik berfokus pada dua hal, yaitu:

1) Proses penyusunan kekuasaan. Level Makro dalam proses penyusunan kekuasaan menggambarkan bahwa PR II memegang kekuasan dari seluruh proses perumusan implementasi kebijakan turunan yang dibuat rektorat dari undang-undang dan peraturanpemerintahterkait dengan dengan masalah administrasi umum dan keuangan. Sedangkan, pada level messo digambarkan tata kelola dan tata kerja organisasi dalam unit unit kerja BAUK serta proses transformasi melalui penguatan kelembagaan untuk mencapai tujuan renstra UNJ 2014. Selain itu, pada level mikro digambarkan bagaimana proses eksekusi rumusan implementasi kebijakan turunan yang dibuat oleh pihak 
rektorat.

mencapai tujuan renstra UNJ 2014.

2) Proses Pengisian Kekuasan. PR II sebagai ketua BAUK memiliki kemampuan dan kewenangan dalam hal menyusun rumusan implementasi kebijakan yang dibuat oleh rektorat dalam BAUK dalam rangka tercapainya tujuan Renstra UNJ 2014 pada level Makro. Sedangkan, pada level messo, PR II memiliki kemampuan dan kewenangan dalam melaksanakan tata kelola dan tata kerja dalam BAUK. Pada level mikro, PD II pada setiap fakultas memiliki kewenangan dalam melakukan eksekusi pada perumusan kebijakan yang dibuat oleh rektorat dalam bidang adiministrasi umum dan keuangan dalam rangka tercapainya tujuan Renstra UNJ 2014. Berpijak pada pemikiran Nee mengenai NIES dikatakan bahwa pada level mikro terdapat komunitas seperti elemen unit kerja bidang administrasi dan keuangan (PD 2) yang memiliki kemampuan untuk membangun sistem perilakuk dalam rangka mengatasi ketidakserasian (decoupling) dan mencapai konsensus (compliance) melalui interaksi dan transaksi berbasis nilai yang tert (embeddedness)

untuk membangun kerangka penguatan kelembagaan sebagai bentuktransformasiuntuk

\section{Tahap 2: Ekspresi Situasi Masalah (Rich} Piture)

Rich picture dari proses penguatan kelembagaan sebagai bentuk transformasi untuk tercapainya Renstra UNJ 2014 dapat dilihat pada Gambar 1 di bawah ini.

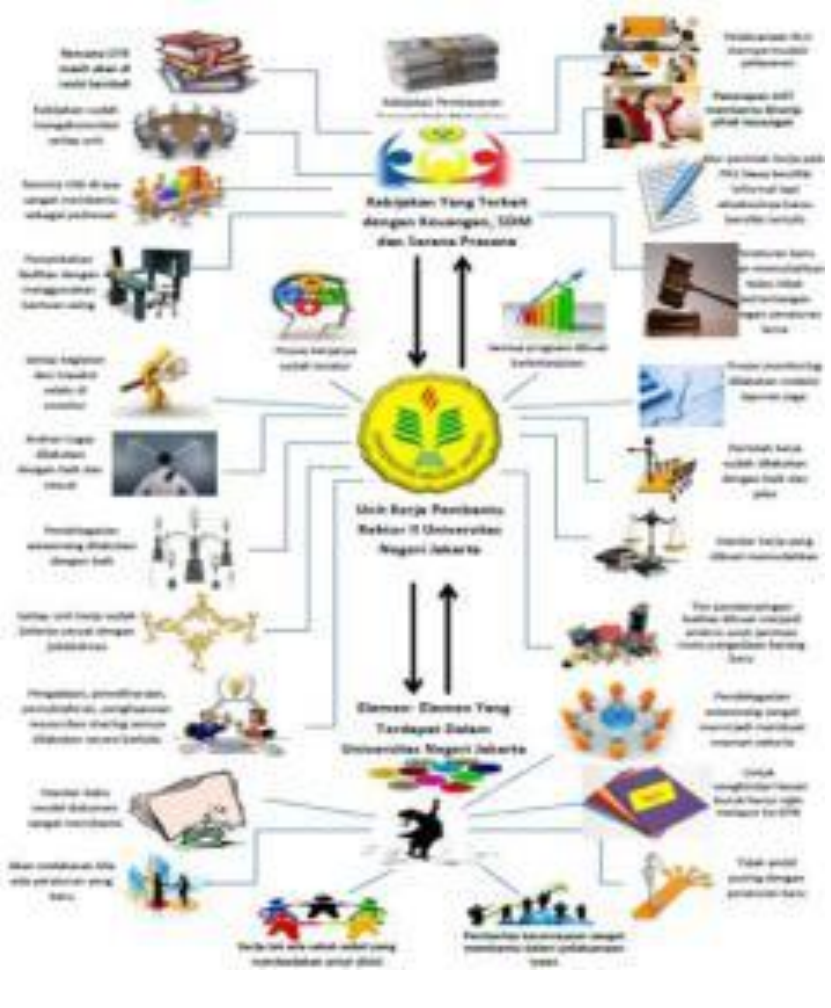

Gambar 1

Rich Picture Renstra UNJ 2014

Sumber: Dokumen Internal Universitas Negeri Jakarta

\section{Tahap 3: Root Definition of Relevan System}

Untuk menguji root definition dilakukan dengan cara melakukan Customers, Actors,

Transformasi, Weltanschaung, Owners, Environment, Efikasi, Efisiensi, dan Efektif (CATWOE) analisis. CATWOE digunakan untuk mengidentifikasi stakeholders yang terlibat, transformasi, weltanschaung (cara 
pandang), dan lingkungan untuk kemudia membangun definisi sistem aktivitas manusia yang dibutuhkan untuk memperbaiki situasi masalah.

\section{Root Definition pada Level Makro (RD1): Kebijakan BAUK}

Root definition dari kebijakan BAUK

pada level makro disajikan pada Tabel 1

di bawah ini.

\section{Tabel 1}

\section{Root Definition pada Level Makro (RD1):} Kebijakan BAUK

\begin{tabular}{|c|c|}
\hline 1 & $\begin{array}{l}\text { Sistem yang dimiliki dan dioperasikan } \\
\text { oleh unit kerja bidang administrasi } \\
\text { umum dan keuangan dalam } \\
\text { mengeksplorasi dan merumuskan } \\
\text { kebijakan (P) melalui aplikasi SSM } \\
\text { untuk melakukan penguatan sebagai } \\
\text { bentuk transformasi kelembagaan (Q) } \\
\text { menuju tercapainya Renstra UNJ 2014 } \\
\text { (R) }\end{array}$ \\
\hline Custo & $\begin{array}{l}\text { Rektor Universitas Negeri Jakarta, Unit } \\
\text { Kerja Bidang Administrasi Umum dan } \\
\text { Keuangan, Kepala Sub Bagian dan } \\
\text { Bagian dalam Unit Kerja Bidang } \\
\text { Administasi Umum dan Keuangan }\end{array}$ \\
\hline Actors & $\begin{array}{l}\text { Rektor Universitas Negeri Jakarta dan } \\
\text { Pembantu Rektor II Universitas Negeri } \\
\text { Jakarta }\end{array}$ \\
\hline Transformasi & $\begin{array}{l}\text { Regulasi bidang administrasi umum } \\
\text { dan keuangan yang mendorong } \\
\text { terwujudnya transformasi kelembagaan } \\
\text { menuju Renstra UNJ } 2014\end{array}$ \\
\hline $\begin{array}{l}\text { Weltans- } \\
\text { chaung }\end{array}$ & $\begin{array}{l}\text { Melalui penguatan sebagai bentuk } \\
\text { transformasi kelembagaan } \\
\text { Renstra UNJ } 2014\end{array}$ \\
\hline Owner(s) & Rektor UNJ dan PR II UNJ \\
\hline Enviro & $\begin{array}{l}\text { Kendala yang dihadapi yaitu anggaran } \\
\text { dan waktu }\end{array}$ \\
\hline E - Efikasi & $\begin{array}{l}\text { Eksplorasi dan perumusan kebijakan } \\
\text { bidang administrasi umum dan } \\
\text { keuangan yang mendorong proses } \\
\text { transformasi melalui penguatan } \\
\text { kelembagaan menuju Renstra UNJ } \\
2014\end{array}$ \\
\hline E - Efisiensi & $\begin{array}{l}\text { Menggunakan sumber keuangan dan } \\
\text { waktu yang optimal }\end{array}$ \\
\hline$E-E f$ & Terc \\
\hline
\end{tabular}

Sumber: Data Diolah Penulis
2. Root Definition pada Level Messo (RD 2): Tata Kelola Kelembagaan Unit Kerja BAUK

Root definition dari Tata Kelola Kelembagaan Unit Kerja BAUK pada level messo disajikan pada Tabel 2 di bawah ini.

Tabel 2

Root Definition pada Level Messo (RD 2): Tata Kelola Kelembagaan Unit Kerja BAUK

\begin{tabular}{|c|c|}
\hline RD 2 & $\begin{array}{l}\text { Sistem yang dimiliki dan dioperasikan } \\
\text { oleh unit kerja bidang administrasi } \\
\text { umum dan keuangan untuk } \\
\text { membentuk tata kelola kelembagaan } \\
\text { (P) melalui aplikasi SSM untuk } \\
\text { melakukan penguatan sebagai bentuk } \\
\text { transformasi kelembagaan } \\
\text { menuju tercapainya Renstra UNJ } \\
2014(\mathrm{R})\end{array}$ \\
\hline Customers & $\begin{array}{l}\text { Rektor Universitas Negeri Jakarta, } \\
\text { Unit Kerja Bidang Administrasi } \\
\text { Umum dan Keuangan, Kepala Sub } \\
\text { Bagian dan Bagian dalam Unit Kerja } \\
\text { Bidang Administasi Umum dan } \\
\text { Keuangan, Elemen dalam Unit Kerja } \\
\text { Bidang Administrasi Umum dan } \\
\text { Keuangan }\end{array}$ \\
\hline Act & $\begin{array}{l}\text { Rektor Universitas Negeri Jakarta dan } \\
\text { Pembantu Rektor II Universitas } \\
\text { Negeri Jakarta }\end{array}$ \\
\hline Transfor & 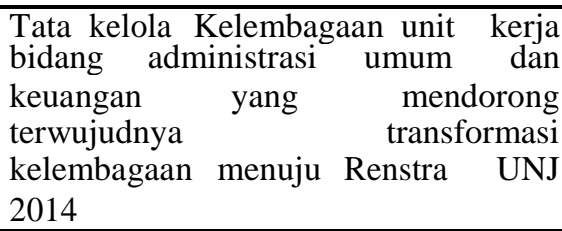 \\
\hline $\begin{array}{l}\text { Weltans- } \\
\text { chaung }\end{array}$ & $\begin{array}{l}\text { Melalui penguatan sebagai } \\
\text { transformasi kelembagaan } \\
\text { Renstra UNJ } 2014\end{array}$ \\
\hline Own & Rektor UNJ dan PR II UNJ \\
\hline Environment & $\begin{array}{l}\text { Kendala yang dihadapi yaitu anggaran } \\
\text { dan waktu }\end{array}$ \\
\hline E - Efikasi & $\begin{array}{l}\text { Pembentukan tata kelola kelembagaan } \\
\text { melalui aplikasi SSM untuk } \\
\text { melakukan penguatan sebagai bentuk } \\
\text { transformasi kelembagaan menuju } \\
\text { tercapainya Renstra UNJ } 2014\end{array}$ \\
\hline E - Efisiensi & $\begin{array}{l}\text { Menggunakan sumber keuangan dan } \\
\text { waktu yang optimal }\end{array}$ \\
\hline E - Efektif & Tercapainya Renstra UNJ 2014 \\
\hline
\end{tabular}

Sumber: Data Diolah Penulis 


\section{Root Definition pada Level Mikro} (RD3): Elemen pada Unit Kerja BAUK Root definition dari elemen pada unit kerja BAUK pada level mikro disajikan pada Tabel 3 di bawah ini.

Tabel 3

\section{Root Definition pada Level Mikro (RD3):} Elemen pada Unit Kerja BAUK

\begin{tabular}{|c|c|}
\hline RD 3 & 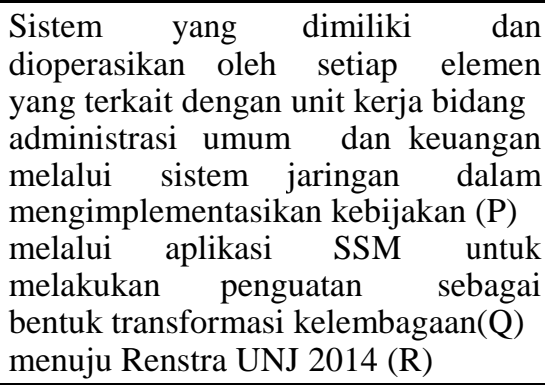 \\
\hline Customers & $\begin{array}{l}\text { Rektor Universitas Negeri Jakarta, } \\
\text { Unit Kerja Bidang Administrasi } \\
\text { Umum dan Keuangan, Kepala Sub } \\
\text { Bagian dan Bagian dalam Unit Kerja } \\
\text { Bidang Administasi Umum dan } \\
\text { Keuangan, Elemen dalam Unit Kerja } \\
\text { Bidang Administrasi Umum dan } \\
\text { Keuangan }\end{array}$ \\
\hline Actors & $\begin{array}{l}\text { Rektor Universitas Negeri Jakarta } \\
\text { dan Pembantu Rektor II Universitas } \\
\text { Negeri Jakarta }\end{array}$ \\
\hline Transformasi & \begin{tabular}{lcr} 
Sistem & jaringan & \multicolumn{2}{r}{ dalam } \\
mengimplemantasikan & \multicolumn{2}{c}{ kebijakan } \\
bidang administrasi & umum dan \\
keuangan yang & mendorong \\
terwujudnya & & transformasi \\
kelembagaan & menuju & Renstra UNJ \\
2014 & &
\end{tabular} \\
\hline Weltanschaung & $\begin{array}{l}\text { Melalui penguatan sebagai bentuk } \\
\text { transformasi kelembagaan menuju } \\
\text { Renstra UNJ } 2014\end{array}$ \\
\hline Owner(s) & Rektor UNJ dan PR II UNJ \\
\hline Environment & $\begin{array}{l}\text { Kendala yang dihadapi } \text { yaitu } \\
\text { anggaran dan waktu }\end{array}$ \\
\hline E - Efikasi & \begin{tabular}{lcr}
\multicolumn{2}{l}{ Pembentukan } & sistem jaringan pada \\
elemen yang & terkait dengan unit \\
kerja bidang administrasi umum dan \\
keuangan & mengimplementasikan \\
kebijakan & untuk $\quad$ melakukan \\
penguatan & sebagai & bentuk \\
transformasi & kelembagaan & menuju \\
Renstra UNJ & 2014 &
\end{tabular} \\
\hline E - Efisiensi & $\begin{array}{l}\text { Menggunakan sumber keuangan dan } \\
\text { waktu yang optimal }\end{array}$ \\
\hline E - Efektif & Tercapainya Renstra UNJ 2014 \\
\hline
\end{tabular}

Sumber: Data Diolah Penulis

\section{Tahap 4: Model Konseptual Dalam}

\section{Penamaan Sistem di dalam Root Definition}

1. Model 1: Kebijakan BAUK pada-Level Makro

Elemen unit kerja BAUK pada level makro meliputi langkah dalam sistem sebagai berikut:

a. Mempelajari kebijakan yang dibuat oleh Mendikbud.

b. Mempelajari dan mengekplorasi kebijakan turunan yang dibuat oleh pihak Rektorat.

c. Membuat rumusan implementasi kebijakan yang dibuat rektorat.

d. Membangun kapasitas SDM dan kelembagaan pada unit kerja BAUK.

e. Menganalisa kriteria tindakan dalam kerangka kelembagaan yang dilakukan setiap elemen unit kerja BAUK.

f. Mempelajari dan menganalisa pengaruh struktur serta historikal pada setiap rumusan keputusan yang dibuat.

g. Menentukan rules, habits, norma dalam pembentukan draf perumusan implementasi kebijakan rektorat.

h. Membangun strategi dalam pelaksanaan hasil rumusan bentuk implementasi kebijakan rektorat dengan regulasi turunannya yang bersifat teknis.

i. Melakukan interaksi dengan setiap elemen dalam unit kerja terkait dengan rumusan implementasi kebijakan rektorat.

j. Membangun konvensi dan hubungan formal pada setiap elemen unit kerja 
BAUK terkait dengan rumusan implemenatsi.

k. Melakukan pengawasan terhadap pelaksanaan rumusan implementasi kebijakan rektorat secara berkala dan berkelanjutan.

\section{Model 2: Tata Kelola Kelembagaan} Unit Kerja BAUK-Level Messo Elemen unit kerja BAUK pada level messo meliputi langkah dalam sistem sebagai berikut:

a. Merekonstruksi bentuk tata kelola kelembagaan unit kerja BAUK.

b. Menentukan kriteria rekonstruksi bentuk tata kelola sebagai bentuk penguatan kelembagaan unit kerja BAUK.

c. Menentukan unsur penguatan dalam bentuk tata kelola kelembagaan unit kerja BAUK.

d. Menganalisa pengaruh struktur tata kelola kelembagaan unit kerja terhadap proses transformasi melalui penguatan lembaga.

e. Menentukan rules, habits, norma dalam unit kerja BAUK terkait dengan bentuk tata kelola.

f. Mengintegrasikan setiap elemen dalam organisasi melalui aturan sosial, aturan kelembagaan, struktur tata kelola dan efisiensi penggunaan sumber daya yang dimiliki unit kerja BAUK.

g. Melakukan pembelajaran interaktif, variasi kreatif, pengetahuan kolektif dan komunikasi sistematis dalam organisasi di setiap tindakan unit kerja BAUK.

h. Melakukan interaksi diantara setiap elemen unit kerja terkait tata kelola unit kerja BAUK.

i. Membangun konvensi dan hubungan sosial melalui umpan balik pada setiap elemen unit BAUK dalam setiap tindakan.

\section{Model 3: Elemen Unit Kerja BAUK-}

\section{Level Mikro}

Elemen pada Unit kerja BAUK dalam model konseptual tiga meliputi:

a. Merekontruksikan pola hubungan dalam sistem jaringan pada elemen di dalam unit kerja BAUK.

b. Menganalisa pengaruh sistem jaringan pada elemen unit kerja BAUK dalam melaksanakan rumusan kebijakan rektorat.

c. Menentukan rules, habits, norma pada setiap elemen unit kerja BAUK dalam mengimplementasikan kebijakan Rektorat.

d. Mengintegrasikan setiap elemen dalam unit kerja BAUK melalui aturan sosial, aturan kelembagaan, dan struktur tata kelola dan efisiensi penggunaan sumber daya dari masing-masing elemen.

e. Melakukan interaksi diantara setiap elemen dalam unit kerja BAUK terkait dengan pelaksanaan rumusan kebijakan rektorat. 
f. Melakukan negosiasi dan kompromi melalui aturan formal dan aturan sosial yang terdapat dalam unit kerja BAUK terkait dengan tindakan setiap elemen dalam melaksanakan kebijakan rektorat.

g. Membangun konvensi dan hubungan sosial melalui umpan balik pada setiap elemen dalam unit kerja BAUK dalam proses implementasi kebijakan rektorat.

h. Sistem pola hubungan melalui sistem jaringan pada setiap elemen unit kerja BAUK dalam implementasi kebijakan rektorat melalui nilai-nilai yang disepakati bersama.

\section{Tahap 5: Perbandingan Model Dengan Dunia Nyata}

Pada level Makro, perubahan tidak hanya dilakukan secara strukutral yang diinginkan tetapi juga secara kultural yang memungkinkan. Pada Level Messo, proses transformasi yang dilakukan adalah membentuk perubahan dengan melakukan penguatan kelembagaan tata kelola dan tata kerja unit kerja BAUK dalam melakukan tugas utamanya yaitu melakukan perumusan implementasi kebijakan yang dibuat oleh rektorat yang terkait dengan masalah keuangan, layanan umum, inventarisasi dan pencatatan asset UNJ, dan segala sesuatu yang terkait dengan sarana prasarana dalam proses pelayanan dan belajar mengajar.

Sedangkan, pada level mikro, proses transformasi dilakukan melalui penguatan kelembagaan mutlak dilakukan pada sistem jaringan yang ada pada setiap pola tindakan dari setiap elemen-elemen unit kerja BAUK bekerja dalam meralisasikan dan mengeksekusi setiap rumusan implementasi kebijakan yang telah dibuat oleh unit kerja ini. Dengan memanfaatkan sistem jaringan yang dimiliki oleh setiap elemen yang terdapat dalam unit kerja ini diharapkan proses realisasi rumusan implementasi kebijakan tersebut bisa berjalan dengan baik dan memenuhi target pelaksaannya, sehingga bisa membantu tercapainya tujuan dari renstra UNJ 2014.

\section{Tahap 6: Perubahan Yang Secara Sistematis} Diinginkan (systemically desirable) dan secara budaya dapat dilakukan (culturally feasible)

Berdasarkan penelitian yang telah dilakukan mulai dari tahap 1 sampai dengan tahap 5, maka proses transformasi yang harus dilakukan adalah sebagai berikut:

1. Merubah pola tata kelola dan tata kerja unit kerja BAUK dalam melakukan proses perumusan implementasi kebijakan yang dibuat oleh pihak rektorat.

2. Penerapan nilai keadilan, persamaan, kebersamaan, kemandirian, dan transparansi sesuai dengan tujuan Renstra UNJ 2014 yang diterapkan dalam tata kelola dan tata kerja pada unit kerja

BAUK dalam melakukan perumusan implementasi kebijakan turunan yang dibuat oleh pihak rektorat.

3. Sistem jaringan yang berupa standar perilaku yang dipakai oleh setiap elemen unit kerja BAUK adalah konvensi serta 
nilai-nilai yang selama ini dijadikan sebagai standar setiap elemen melaksanakan tata kerja pada setiap unit kerja mereka sendiri.

4. Setiap tindakan yang dilakukan semuanya terikat dengan nilai-nilai yang telah lahir dan berkembang pada sistem tata kerja dan tata kelola di lingkungan kerja UNJ pada umumnya dan unit kerja BAUK pada khususnya.

\section{KESIMPULAN DAN}

\section{SARAN Kesimpulan}

Berdasarkan hasil penelitian, maka

didapatkan kesimpulan sebagai berikut:

1. Pada level makro, dijelaskan bagaimana unit kerja BAUK melakukan proses perumusan implementasi kebijakan yang dibuat oleh pihak rektorat. Dalam melaksanakan tugasnya unit kerja BAUK selalu melibatkan setiap elemen yang ada sesuai dengan kebutuhan dari proses belajar mengajar dari masing-masing fakultas. Proses perumusan kebijakan yang dilakukan sudah sesuai dengan pendekatan Renstra, yaitu harus sistemik, imajinatif, dan tidak terikat oleh kontinuetas kegiatan yang telah lalu. Tetapi dalam kasus pelaksanaan kebijakan BLU, setiap elemen unit kerja bidang merasa pelaksanaan BLU sebenarnya mempermudah, hanya saja mungkin masih kerepotan dalam membuat laporan keuangan. Pelaksanaan rumusan implementasi kebijakan yng dilakukan oleh unit kerja ini dirasa sudah cukup maksimal walaupun dalam implementasinya masih menemui kesulitan-kesulitan cukup berarti.

2. Pada level messo, dimana dijelaskan bagaimana bentuk tata kelola unit kerja BAUK UNJ sudah dilaksanakan sesuai dengan landasan yang terdapat pada rencana strategis UNJ. Dalam pelaksanaan proses tata kelola, para staf dalam unit ini masih mendapatkan masalah. Masalah yang terjadi pada tata kelola dan tata kerja pada unit kerja BAUK dalam melaksanakan sebagaian besar tugasnya adalah kurang kuatnya akuntabilitas dari sumber daya manusia yang terdapat dalam unit kerja tersebut. Masalah yang ditemui lainnya dalam proses tata kelola pada unit ini adalah masalah sumber daya manusia terutama masalah keterampilan. Dalam sistem tata kelola tetap tergantung dari yang melakukannya. Pada pelaksanaan tata kelola yang didasarkan pada standar yang ada di BLU, sistem yang dipakai sebenarnya tujuannya mempermudah pelaksaan tugas setiap elemen pada unit kerja bidang administrasi umum dan keuangan, hanya saja mungkin setiap elemen agak kerepotan dalam membuat laporan keuangannya.

3. Pada level mikro, disini dijelaskan bagaimana sistem jaringan yang ada pada setiap elemen pada unit kerja BAUK. Setiap elemen memiliki tata perilaku, norma, kebiasaan, peraturan formal maupun informal dalam melakukan 
eksekusi setiap rumusan kebijakan yang telah dibuat oleh unit kerja ini. Tetapi setiap elemen juga merasakan ada masalah yang menjadi kendala dalam melaksanakan tugas mereka. Setiap tindakan yang dilakukan semuanya terikat dengan nilai-nilai yang telah lahir dan berkembang pada sistem tata kerja dan tata kelola di lingkungan kerja UNJ pada umumnya dan unit kerja BAUK pada khususnya. Setiap nilai-nilai baik berupa konvensi ataupun peraturan formal ini proses sosialisasinya sudah terjadi secara turun temurun dari mulai lembaga pendidikan ini berdiri dan terus mengalami perubahan sesuai dengan tuntutan dan perkembangan zaman. Nilainilai dan tata perilaku yang dipakai oleh setiap elemen pada unit kerja BAUK dipakai untuk setiap tindakan untuk tercapainya Renstra UNJ 2014.

4. Bentuk transformasi yang telah dilakukan oleh pihak UNJ adalah dengan melakukan penguatan kelembagaan dalam hal tata kelola setiap unit kerja yang ada di universitas ini, termasuk dalam unit kerja BAUK. Proses penguatan yang dilakukan adalah dengan melakukan perubahan bentuk tata kelola setiap unit kerja. Penguatan ini dilakukan dengan cara merubah standar tata kelola berdasarkan pada rancangan tata kerja dan organisasi badan layanan umum. Tata kelola ini didasarkan pada PK-BLU secara konsep merupakan badan yang memberikan pelayanan kepada masyarakat. UNJ juga salah satu kampus penerap PK-BLU dalam praktik pendidikan yang dijalankannya. BLU merupakan suatu kebijakan yang memberikan kebebasan kepada pihak kampus dalam hal pengelolaan baik secara keuangan, administrasi, dan yang lainnya.

\section{Saran}

Adapun saran yang dapat diberikan melalui penelitian ini adalah bahwa dalam melakukan proses transformasi berupa penguatan kelembagaan dalam tata kelola setiap unit kerja di UNJ haruslah memperhatikan unsur-unsur transparansi dan akuntabilitas, standarisasi layanan pendidikan, system pengendalian manajemen, penggunaan sumber daya yang efisien, serta system informasi manajemen pendidikan.

\section{DAFTAR PUSTAKA}

Asropi. Membangun Key Performance Indicator Lembaga Pelayanan Publik. Manajemen Pembangunan 57(1):1-6, 2007.

\section{Azis. A. Memehami Fenomena Sosial Melalui} Studi Kasus. dalam Bungin, B. Analisis Data Penelitian Kualitatif. Jakarta: PT Rajagrafindo Persada, 2003.

Ball, S. J. Case Study. Dalam Kuper, A.,and kuper, J. (editor). The Social Science Encyclopedia, Third Edition (p.92). Routledge. London, 2004.

Barzeley, M.. Breaking Through Bureaucracy:

A New Vision for Managing in Government, Berkeley and Los Angeles: University of California Press, 1992. 
Brodjonegoro, S.S. Higher Education Reform in Indonesia. Ministry of National

Education, Indonesia, 2002.

Burrell, G. dan G. Morgan. Sociological Paradigms and Organizations and Society. 5-28, 1975.

Bungin, B. Penelitian Kualitatif: Komunikasi, Ekonomi, Kebijakan Publik, dan Ilmu Sosial Lainnya. Kencana. Jakarta, 2007.

Carruthers, B.G. Accounting, Ambiguity, and The New Institutionalism, Accounting, Organizational and Society 20 (4):313328, 1995.

Chariri, A. Landasan Filsafat dan Metode Penelitian Kualitatif. Paper Disajikan pada Workshop Metodologi Penelitian Kuantitatif dan Kualitatif, Laboratorium Pengembangan Akuntansi (LPA), Fakultas Ekonomi Universitas Diponegoro Semarang, 31 Juli- 1 Agustus 2009. http://www.google.com. 30 Januari 2011.

Checkland, Peter and Jim Scholes. Soft System Methodology in Action. . Chichester: John Wiley and Sons Ltd, Baffins, 1990.

Cresswell, J.W. 2007. Qualitative Inquiry and Research Design: Choosing Among Five Approaches. Sage Publication Inc. USA, 2007.

Departemen Keuangan RI. Enterprising The Government menjadi ruh PK BLU. n.d. 3 Januari 2014. <http:// www.ppkblu.depkeu.go.id/index.php/ baca/berita/41/enterprising-thegovernment-menjadi-ruh-pkblu\#sthash.9bkTUCRx.dpuf>.

Direktur Jenderal Perbendaharaan Kementerian Keuangan RI. "Materi Penilaian Kinerja Satker BLU pada Rakor Kinerja BLU 2013." Peningkatan Kinerja Badan Layanan Umum dalam rangka penyehatan Fiskal Guna Mendorong Pertumbuhan Ekonomi Berkelanjutan, 2013.
Djamhuri, A. A Case Study Of Governmental Accounting And Budgeting Reform At Local Authority In Indonesia. An Institutionalist Perspective. Disertasi Tidak Dipublikasikan. Universiti Sains Malaysia, 2009.

Effendi. S. Pengelolaan Perguruan Tinggi Menghadapi Tantangan Global.http:// sofian.staff.ugm.ac.id/artikel/Efendi. 28 Januari 20011.2003.

Harrun. Reformasi Akuntansi dan Manajemen Sektor Publik di Indonesia. Salemba Empat. Jakarta, 2009.

Hartley, J. Essential Guide To Qualitative Methods In Organizational Research. (Ed. Cassell,C Dan Symon, G) : Sage Publication Ltd, 2004.

Hood, C. The New Public Management in" the 1980s". Variations on a theme, Accounting, Organization and Society 20 (2/3): 93-109, 1995.

Hopwood, A. The Archaeology of Accounting Systems. Accounting, Organizations and Society, 12(3), 207-234, 1987.

Hopwood, A. Accounting and Organisational Change. Accounting, Auditing \& Accountability Journal 3 (1): 7-17. 1990.

Huberman, A.M., \& M.B. Miles. The Qualitative Researchers's Companion. Thousand Oaks, California: Sage Publications, 2002.

Ikatan Akuntan Indonesia. Standar Akuntansi Keuangan. Jakarta: Salemba Empat, 2012.

Irvine, $\mathrm{H}$ dan $\mathrm{M}$. Gaffikin. Methodological Insights Getting In, Getting On and Getting Out: Reflections on A Qualitative Research Project. Accounting, Auditing \& Accountability Journal 19(1): 115-145, 2006.

Komite Standar Akuntansi Pemerintahan. Standar Akuntansi Pemerintah. Jakarta: Salemba Empat, 2012. 
Kuswarno, E. Metodologi Penelitian Komunikasi Fenomenologi: Konsep, Pedoman, dan Contoh Penelitian. Widya Padjadjaran. Bandung, 2009.

Lippi, A. One theory, many practices. Institutional allmorphism, in the managerialist of Italian local goverment, Scandinavian Journal Management 16 (2000): 455-477, 2000.

Lukman, Mediya. Badan Layanan Umum dari Birokrasi Menuju Korporasi. Jakarta: Bumi Aksara, 2013.

Makhmudi. NPM Manajemen Baru Sektor Publik. Jurnal Sinergi Kajian Bisnis dan Manajemen 6(1): 69-76.

Miller, P. Dan T. O'Leary. 1987. Accounting and The Construction of The Governable Person. Accounting, Organizations and Society 12 (3): 235-265, 1987.

Moleong, L. J. Metodologi Penelitian Kualitatif. PT Remaja Rosdakarya. Bandung, 2004.

Morgan, G. Accounting as Reality Construction: Toward a New Epistomology for Accounting Practice. Accounting, Organizations and Society 13 (5): 477-85, 1988.

Mulyadi. Sistem Akuntansi, Cetakan keempat. Jakarta: Salemba Empat, 2008.

Myers, M. D. 2009. Qualitative Research In Business And Management. London: Sage Publication, 2009.

Nelson, L. A Case Study In Organisational Change: Implications For Theory. The Learning Organisation.10 (1): 18-30, 2003.

Noerdiawan, Deddy dkk,. Akuntansi Pemerintahan, Cetakan kedua. Jakarta: Salemba Empat, 2007.

Pribadi, Ulung dkk,. "Evaluasi Kebijakan Pengelolaan Badan Layanan umum: JKSG Paper No. 003/JKSG/2012." n.d. 4 Januari 2014. <https:// www.academia.edu/270773>.
Pusat Kajian Manajemen Kebijakan LAN RI.

Manajemen Kinerja, Modul-Modul Penerapan. LAN RI, 2009.

Rahayu, S. Menyibak Proses Penyusunan Anggaran Pemerintah Daerah (Studi Fenomenologi pada satu SKPD di Propinsi Jambi. Tesis Tidak Dipublikasikan. Universitas. Brawijaya. Malang, 2007.

"Sistem Akuntansi Universitas Negeri Jakarta." Draf UNJ, 2013.

Salim, A. 2001. Teori dan Paradigma Penelitian Sosial. Yogyakarta: PT Tiara Wacana, 2001.

Siddiquee, N. A. Public Management reform in Malaysia recent initiatives and experiences. International Journal of Public Sector Management 19(4): 339358, 2006.

Sjafrizal. Ekonomi Regional, Teori dan Aplikasi. Niaga Swadaya. Padang, 2008.

Stiglits, Josep E. Economics of The Public Sector, Third Edition. New York: W.W. Norton \& Company, 2000.

Sugiyono. Memahami Penelitian Kualitatif, Cetakan Ketujuh. Bandung: Alfabeta, 2012.

Sulistiyono, S.T. Higher Education Reform In Indonesia At Crossroad. Paper Presented at the Graduate School of Education and Human Development, Nagoya University, Nagoya, Japan: 26 July, 2007.

Sutopo. H. B. Penelitian Kualitatif. Sebelas Maret University Press. Surakarta, 2002.

Tata Kelola Universitas Negeri Jakarta. UNJ, 1999.

Triyuwono. Organisasi dan Akuntansi Syari'ah. LkiS. Jogjakarta, 2000.

Triyuwono. Perspektif, Metodologi, dan Teori Akuntansi Syariah. Rajawali Pers. Jakarta, 2009. 
Universitas Negeri Jakarta. Universitas Negeri Jakarta. n.d. 2 Maret 2015. <http:// www.unj.ac.id>.

Waluyo, Indarto. "Badan Layanan Umum Sebuah Pola Baru Dalam Pengelolaan Keuangan di Satuan Kerja Pemerintah." Jurnal Pendidikan Akuntansi Indonesia, Vol. IX. No. 2 (2011).

Widjajanto, Nugroho. Sistem Informasi Akuntansi. Jakarta: Erlangga, 2001.

Willis. J. W. Foundation of Qualitative Research. Interpretive and Critical Approaches. USA: Sage Publication, 2007.

Yin, R., K.. Case Study Research Design And Methods (Third Ed.). Thousand Oaks, C.A.: Sage Publications, 2003.

Wijayanti. Reformasi Sistem Akuntansi: Kasus Pada Pemerintah Propinsi Kalimantan Selatan. Tesis Tidak Dipublikasikan. Universitas Brawijaya. Malang, 2006.

Undang-undang No 17 tahun 203 tentang Keuangan Negara

Undang-undang Nomor 1 tahun 2004 tentang Perbendaharaan Negara

Undang-undang No 15 tahun 2004 tentang Pemeriksaan Pengelolaan dan Tanggung Jawab Keuangan Negara

PP No 23 tahun 2005 tentang Pengelolaan Keuangan Badan Layanan Umum

\section{Peraturan Menteri Keuangan Nomor 76/ PMK.05/2008 Tentang Pedoman Akuntansi dan Pelaporan Keuangan Badan Layanan Umum}

Peraturan Menteri Keuangan Nomor 238/ PMK.05/2011 Tentang Pedoman Umum Sistem Akuntansi Pemerintahan

Peraturan Direktur Jenderal Perbendaharaan Nomor Per-33/PB/2011 Tentang Mekanisme Pengesahan Pendapatan dan Belanja Satuan Kerja Badan Layanan Umum
Peraturan Direktur Jenderal Perbendaharaan Nomor Per-36/PB/2012 Tentang Pedoman Penilaian Kinerja Keuangan Satuan Kerja Badan Layanan Umum

Kementerian Pendidikan dan Kebudayaan RI, 2012. Pedoman Penyusunan Laporan Keuangan Badan Layanan Umum (BLU) di Lingkungan Kemendikbud Berdasarkan SAP.

Biro Administrasi Umum dan Keuangan Universitas Negeri Jakarta, 2010

Mekanisme Pengelolaan Keuangan Badan Layanan Umum Universitas Negeri Jakarta 